\title{
NACIONALISMOS E INTERNACIONALISMO: UM DEBATE ENTRE MICHAEL LÖWY E MICHEL CAHEN
}

Ângela Lazagna
Michel Löwy

Michel Cahen

\section{RESUMO}

Este artigo consiste em um debate realizado entre Michel Löwy e Michael Cahen em meados dos anos 1990 e revisto para esta publicação. Mesmo que a discussão refira-se a acontecimentos que até certo ponto podem ser considerados datados, a preocupação de fundo que é comum a esses artigos concede-lhes atualidade: a necessidade do aprofundamento de uma reflexão, a partir da teoria marxista, sobre o problema dos nacionalismos e do internacionalismo em tempos de mundialização. Esse aprofundamento, segundo os autores, faz-se necessário sobretudo por meio de uma reflexão que rompa criticamente com uma visão eurocêntrica dos diferentes nacionalismos e que supere a atitude de muitos marxistas de desprezarem tudo aquilo que não seja diretamente relevante à "consciência de classe".

PALAVRAS-CHAVE: nacionalismos; internacionalismo; marxismo; eurocentrismo; mundialização; consciência de classe.

\section{APRESENTAÇÃO ${ }^{1}$}

\section{Ângela Lazagna}

Os artigos de Michael Löwy, Nacionalismos do Sul, e de Michel Cahen, Nacionalismos de Terceiro Mundo. Para um debate, em resposta a Michael Löwy, formaram parte de um debate publicado na revista teórica mensal Critique communiste, da Liga Comunista Revolucionária (LCR), entre 1995 e 1997. Mesmo que a discussão refira-se a acontecimentos que, em certo sentido, podem ser considerados datados, a preocupação de fundo comum a esses artigos concedelhes uma atualidade incontestável: a necessidade do aprofundamento de uma reflexão, a partir da teoria marxista, sobre o problema dos nacionalismos e do internacionalismo em tempos de

\footnotetext{
1 Agradeço a Michael Löwy e a Michel Cahen por autorizarem a publicação dos seus artigos, bem como pela revisão da minha tradução ao português dos seus textos. É imprescindível ressaltar que, na altura da redação desta apresentação e das traduções dos artigos subseqüentes, eu realizava um estágio de doutorado no Institut d'Études Politiques - Université Montesquieu Bordeaux IV -, apoiado pela Coordenação de Aperfeiçoamento de Pessoal de Nível Superior (Capes), o que permitiu o acesso a uma ampla bibliografia, bem como a importantes interlocutores (nota da tradutora, Ângela Lazagna).
}

mundialização. Esse aprofundamento, segundo os autores, faz-se necessário sobretudo por meio de uma reflexão que criticamente rompa com uma visão eurocêntrica dos diferentes nacionalismos e que supere a atitude de muitos marxistas de desprezarem tudo aquilo que não seja diretamente relevante para a "consciência de classe”.

As questões enfrentadas por Löwy transitam, portanto, por uma abordagem - e por seus dilemas - da tradição marxista em relação à questão nacional. Justamente, a inspiração do seu primeiro livro que se debruça abertamente sobre esse tema (infelizmente, ainda não publicado no Brasil), Les marxistes et la question nationale 18481914: études et textes (LÖWY, HAUPT \& WEILL, 1974), resultou de um curso saudavelmente polêmico, segundo o próprio autor (cf. REIS \& GOMES, 1996, p. 9), ministrado com o cientista político Nicos Poulantzas - cujo esforço de construção de uma teoria do Estado de tipo capitalista somou-se ao corpus teórico da escola althusseriana dos anos 1960 e 1970

Ao oferecer-nos um vasto - apesar de resumido - mapeamento histórico de vários movimentos nacionalistas (Ásia, África, Oriente Médio, 
América Latina), Michael Löwy tem como pressuposto o crescimento dos nacionalismos enquanto fenômeno que, ao menos em parte, contrapõese à mundialização da economia. $\mathrm{O}$ autor pergunta-se - fornecendo-nos, nesse sentido, algumas pistas para a reflexão de uma questão extremamente complexa - como os nacionalismos de tipo emancipador podem contribuir para a luta internacionalista contra o imperialismo e o capitalismo, ressaltando, contudo, que a fronteira entre os nacionalismos é móvel, "considerando que certos movimentos são, por sua vez, libertadores e opressores ou transformam-se de democráticos em agressivos” (LÖWY, 1995-1996, p. 77).

Mas a motivação que perpassa seu artigo detalhada em seu livro Nacionalismos $e$ internacionalismos: da época de Marx até nossos dias (LÖWY, 2000)² - é a constatação de que grande parte do pensamento marxista, em virtude do economicismo, tendeu a subestimar o papel da questão nacional bem como a importância da libertação nacional dos povos dominados ao "[...] esquecer, negligenciar ou, ao menos, subestimar as forças opressoras que não são as de opressão de classe: nacional, racial ou sexual" (LÖWY, 1997, p. 83). Se o marxismo deve ao conceito de "imperialismo" a possibilidade de evitar as armadilhas do falso universalismo eurocêntrico, ele não pode, segundo Löwy (1995-1996, p. 81), “ignorar impunemente a importância das culturas nacionais ou a legitimidade da luta pelos direitos nacionais democráticos”.

Cabe aqui acrescentarmos um breve comentário à reflexão de Löwy sobre um nacionalismo de tipo emancipador latino-americano (da Bolívia e do México, por exemplo), cujos atuais contornos foram sendo esquadrinhados nas últimas décadas: o movimento dos indígenas pelo reconhecimento dos direitos nacionais e culturais dos seus povos, em coalizão com outros grupos ou classes oprimidos. Löwy detém-se, nesse caso, no conteúdo da resolução adotada por muitas organizações indígenas mexicanas na Convenção Nacional Democrática convocada pelos zapatistas em Chiapas, em novembro de 1994, cujo documento denuncia o caráter centralizador e homogeneizador do Estado e reivindica um autonomismo político que reconheça, de fato, a existência do pluralismo

2 Trabalho aqui com a edição francesa desse livro (LÖWY, 1997) (N. T.). e aceite a participação efetiva dos povos indígenas na vida democrática. Esses movimentos, que se contrapõem a um longo processo histórico de dominação - agravada pela fase neoliberal do capitalismo - imposta a esses povos, trazem à tona novas idéias de nações e de modalidades de luta anti-imperialista, o que mais uma vez evidencia que a tradição marxista deve superar muitas de suas fórmulas explicativas dicotômicas - o internacionalismo em detrimento dos nacionalismos, as classes sociais em detrimento das múltiplas etnias, a nação enquanto sinônimo de Estado (daí advindo a idéia de que todo movimento nacionalista é, por princípio, "burguês") - para viabilizar uma análise que contemple os alcances e os limites da construção de um projeto de "superação de todas as formas de opressão”.

Alguns dos argumentos esgrimidos por Michael Löwy foram, nesse sentido, contestados por Michel Cahen. Se, em princípio, aquele adverte que a subestimação, por parte da tradição do marxismo, ao tratar a questão nacional é evidente, Cahen, por sua parte, desvela um outro "vazio" ainda mais premente: o tratamento da questão da etnicidade política e da sua relação com as classes sociais, com os movimentos de libertação colonial, bem como com os movimentos nacionalistas. Alguns dos problemas identificados pelo autor e que estariam na origem da "anti-etnicidade dos marxistas" fundar-se-iam em: 1) identificação da etnia à "raça"; 2) visão reducionista da etnia como resultado de uma "invenção do capitalismo, do imperialismo ou do stalinismo”; 3) concepção eurocêntrica e jacobina da nação, que acaba por reduzi-la ao Estado (ganhando força uma análise do Estado-nação em vez do "Estado de uma nação") e 4) redução "da análise do sentimento nacional das pessoas” à “análise da teoria da nação”. O autor também ressalta, em um outro artigo, que o resultado político dessa concepção impediria "[...] as correntes marxistas, tanto na Europa como no Terceiro Mundo, de tentar tomar a direção dos movimentos étnico-nacionais, repelindoos imediatamente em direção às correntes autenticamente reacionárias” (CAHEN, 1997, p. 167).

Ainda segundo Cahen, nações e etnias devem ser apreendidas como fenômenos de cristalização identitária totalizante, cujas duração e intensidade podem variar; se "[...] todas as nações são etnias, mas [se] nem todas as etnias são nações” (idem, p. 182), podemos daí apreender que a dinâmica da luta de classes ocorre, justamente, em um ter- 
reno permeado de complexidades históricoidentitárias, de modo que "[...] algumas formas de opressão, ainda que integradas global e indiretamente ao capitalismo, podem ser-lhe anteriores e não diretamente classistas - o que, por sua vez, não significa em absoluto que elas não possam ser integradas ao programa libertador de um movimento classista" (CAHEN, 1999, p. 128).

No caso particular dos Palop (Países Africanos de Língua Oficial Portuguesa), Cahen rompe com um conjunto de análises que classifica a luta anticolonial ocorrida nessas formações sociais como "lutas de libertação nacional”. Logo, a crise do Estado na África a que assistimos após os trágicos períodos de guerra civil que assolaram esses territórios é, de fato, a crise decorrente da ausência dos estados-nação, a crise dos estadosterritório nos quais se ausenta uma legitimação moderna. O processo, por exemplo, da produção da "nação moçambicana" e a extensão da nação por toda a sua população foi - e ainda é -, segundo Cahen, o fio condutor do projeto político opressor de um partido-Estado: a Frelimo (Frente de Libertação de Moçambique). Esse é um projeto que não possui como princípio a valorização das etnicidades (isto é, das nações pré-coloniais) - e a possível produção de uma nova "pan-identidade" - mas que, ao contrário, impõe uma "nova identidade" - a construção do "Homem Novo" - como antagonista às identidades precedentes (CAHEN, 1997).

A estreita identificação entre Estado e nação o primeiro como responsável pela formação da segunda - reforça um dos principais traços do Estado capitalista, já sublinhado por Nicos Poulantzas em seu livro Poder político e classes sociais (POULANTZAS, 1975): a imposição da unificação dos indivíduos de uma sociedade "na universalidade política do Estado-nação”. A nação, concebida dentro dos limites dessa concepção, opera antes de tudo por meio de uma lógica supraclassista e supra-identitária e quase sempre homogeneizadora, no sentido de garantir a unidade de uma maioria social "instável” que legitime os interesses de grupos sociais "em 'interesses nacionais', de molde a legitimar a imposição de sua plataforma político-programática específica” (BRAGA, 2005, p. 182). Isso fica evidente quando nos referimos, de acordo com Tambiah, à idéia de Estado-nação secular - sobretudo o Estadonação europeu ocidental - "que foi o resultado de uma série de acontecimentos muito especiais, incluindo sublevações sociais, tensões internas, revoluções e guerras separatistas entre estados" (TAMBIAH, 1997, p. 3). Nesse sentido, segundo esse autor, uma reflexão sobre o que ele denomina de "etnonacionalismo" não pode permanecer refém do modelo universalista de Estado-nação europeu original que as potências imperiais procuraram transplantar "paras as [suas] colônias e territórios dependentes do Terceiro Mundo" (idem, p. 2). Daí advém, portanto, a necessidade de apreensão do "significado latente e [das] repercussões políticas concretas [do] [...] fenômeno [dos nacionalismos]", por meio da caracterização das “forças e interesses sociais subjacentes à invocação do povo-nação enquanto figura jurídico-política de justificação de determinado tipo de ação social” (BRAGA, 2005, p. 182).

A crítica a uma concepção que reduz os muitos nacionalismos a um sinônimo de retrocesso e de reacionarismo procura, certamente, expulsar as análises meramente economicistas dos processos etnopolíticos. Porém, muitas vezes, esse economicismo retorna, por assim dizer, pela porta dos fundos, sob novas formas e disfarces: quando a análise omite-se da tentativa de apreensão de lutas e de contradições que não estão imediatamente subordinadas às classes sociais (nesse caso entendidas como classes fundamentais). Longe de pretender esgotar os múltiplos eixos da problemática, a publicação deste debate procura iluminar - ao menos em parte - alguns caminhos percorridos pela tradição marxista, mas, desta vez, sob o prisma de novos universos empíricos e contextos sociopolíticos. 


\section{NACIONALISMOS DO SUL ${ }^{3}$}

\section{Michael Löwy}

A escalada de nacionalismos é um fenômeno mundial que parece, ao menos em parte, ser uma reação à mundialização da economia. No entanto, em cada região do mundo - e em cada país - são também as condições específicas que favorecem o desenvolvimento dos movimentos identitários e nacionais.

Esses movimentos podem ser, de acordo com cada caso, ora democráticos e emancipadores, pois que reagem às formas de opressão econômica, política e cultural; ora regressivos, intolerantes, agressivos, voltados contra as minorias ou nações dominadas. A fronteira entre ambos é móvel, considerando que certos movimentos são, por sua vez, libertadores e opressores ou transformamse de democráticos em agressivos.

Essas duas formas de nacionalismo também existem nos países do Sul, ou seja, na periferia dependente do sistema capitalista mundial (a expressão "Terceiro Mundo" nada quer dizer após o desaparecimento do "Segundo Mundo", chamado de socialista). Já é tempo de iniciarmos sobre essa questão uma reflexão que não seja tributária nem do eurocentrismo, dominante na atual conjuntura, nem do "terceiromundismo" ingênuo. Nem todo movimento nacional no Sul é, ipso facto, progressista ou democrático, da mesma maneira que nem todo movimento anti-ocidental é, apesar disso, "totalitário".

Historicamente, todos os grandes movimentos revolucionários autênticos dos países do Sul têm sido, simultaneamente, movimentos de libertação nacionalista e social, combinando estreitamente a emancipação anticolonial e o anti-imperialismo à emancipação dos trabalhadores das cidades e do campo. Isso vale para a Revolução Chinesa, para as revoluções indochinesas, para a Revolução Mexicana - "interrompida” no início do século XXI - e para as revoluções cubana e nicaragüense.

Muitos movimentos emancipadores e de libertação nacional desenvolveram-se, ao longo dos

\footnotetext{
3 Artigo originalmente publicado em Löwy (1995-1996).
}

últimos anos, na África, na Ásia e no Oriente Médio (abordaremos o caso da América Latina separadamente). Mas é necessário sublinhar que a maioria desses movimentos - tais como aqueles do Curdistão, da Palestina, do Timor, do Sudão, do Sri Lanka, da África do Sul, da Eritréia - não se confrontam diretamente com o imperialismo ocidental, mas com formas locais de opressão nacional. Com exceção da onda de protesto popular no mundo árabo-muçulmano contra a I Guerra do Golfo e de algumas mobilizações pontuais contra o Fundo Monetário Internacional (FMI) na África do Norte, o nacionalismo anti-imperialista e anticolonialista parece que não representou um papel importante ao longo do último período. Ainda é muito cedo para saber se se trata de um fenômeno conjuntural ou de uma perda de influência em proveito das formas regressivas de recuo identitário, como o integrismo religioso. As Filipinas são, talvez, um dos raros países dessas regiões onde o movimento de libertação nacional (dirigido pelos comunistas) fixa-se em objetivos diretamente anti-imperialistas.

Esses movimentos são de natureza muito diversa: o comunismo mais ou menos ortodoxo, ou seja, de inspiração soviética ou chinesa (o Partido Comunista (PC) Palestino, o PC Sul-Africano, o PC das Filipinas), o "nacional-comunismo" (o PKK do Curdistão), o nacionalismo de esquerda (o Congresso Nacional Africano (ANC), a Frente Popular de Libertação da Eritréia, os Tigres do Eelam do Sri Lanka, a esquerda palestina), o nacionalismo em geral (o El Fatah ${ }^{4}$, o PDK curdo). No Timor Leste, deparamo-nos com um movimento sui generis, originário de um cristianismo de esquerda, a Frente Revolucionária do Timor Leste Independente (Fretilin), que conduz uma difícil luta face à esmagadora superioridade militar da Indonésia ${ }^{5}$. Em certos casos, as rivalidades

\footnotetext{
${ }^{4}$ El Fatah: Movimento de Libertação da Palestina (nota da tradutora).

5 É necessário ter em mente que o artigo de M. Löwy foi publicado em 1995-1996: em 1999 o Timor Leste via referendo proclamou-se independente da Indonésia, situação consolidada em 2002 (nota do revisor).
} 
internas ligadas a razões políticas pouco claras por exemplo, ao Curdistão iraquiano ou ao Sul do Sudão - fragilizam o movimento e fazem o jogo dos opressores.

Ao menos em dois países, os movimentos de libertação nacional de matiz progressista têm obtido vitórias importantes: na Eritréia, com a derrota do regime militar etíope e o reconhecimento do direito à independência do povo eritrense, e, é claro, na África do Sul, com o fim do apartheid e as primeiras eleições por sufrágio universal, levando ao governo o ANC de Nelson Mandela. Mas esse está longe de ser o caso da Palestina, apesar dos "acordos de paz" de Oslo. Assim, encontramos nessa parte do mundo formas agressivas e reacionárias de nacionalismo nos conflitos entre os estados - por exemplo, a atroz guerra entre Irã e Iraque ou os periódicos enfrentamentos entre Paquistão e Índia. Entretanto, os movimentos identitários mais regressivos não são propriamente nacionalistas, mas de caráter tribal (freqüentemente provocados ou manipulados pelas antigas potências coloniais), religioso ou “comunalista”. É verdade que o nacionalismo expansionista pode, em certos casos, utilizar para o seu próprio proveito a religião, como no caso do regime dos mulás, no Irã.

O integrismo religioso, nomeadamente islâmico, aparece mais como um rival ou mesmo como um adversário dos movimentos nacionais do mundo árabo-muçulmano; apenas excepcionalmente ele pode ser portador de uma reivindicação nacional, como por exemplo no Líbano ou na Palestina. No subcontinente indiano, os conflitos religiosos entre fundamentalistas hinduístas e muçulmanos são os responsáveis pelos enfrentamentos trágicos e mortais no seio da população, sendo cada comunidade minoritária vítima de violências e massacres. O caso do Sri Lanka é um pouco diferente, o "comunalismo" assumindo mais um matiz nacional ou etnolingüístico no conflito entre a maioria cingalesa (e budista) e a minoria tâmil, mesmo que a dimensão religiosa não esteja ausente. É por essa razão que podemos considerar o combate dos tâmeis como um movimento de libertação nacional.

Quanto aos movimentos ditos tribalistas - ainda que esse termo nem sempre corresponda a uma realidade étnica ou cultural precisa -, eles são freqüentemente manipulados segundo objetivos reacionários contra o nacionalismo: esse é o caso das forças contra-revolucionárias das antigas colônias portuguesas (como a Resistência Nacional Moçambicana (Renamo) ou a União Nacional para a Independência Total de Angola (Unita)) ou da Inkhata $^{6}$, na África do Sul. Todas as três foram, durante muito tempo, sustentadas pelos dirigentes do apartheid sul-africano (e pelos Estados Unidos), em nome da luta contra o comunismo. Pior ainda: a bandeira da "purificação tribal” pode, quando apoiada por forças neocoloniais, conduzir a um verdadeiro genocídio, como ao que recentemente assistimos em Ruanda [em 1994]. Se os conceitos europeus de "nacionalismo" ou de "racismo" dificilmente se aplicam aos hutus, cujos dirigentes foram os responsáveis pelo massacre, é apenas uma referência identitária de tipo (real ou fictício) "étnico" que serviu de ideologia a um dos piores crimes contra a humanidade das últimas décadas.

O desenvolvimento dos integrismos religiosos, dos tribalismos e dos "comunalismos" é freqüentemente beneficiado pelo fracasso dos governos nacionalistas “de esquerda” ou laicos por exemplo, na África negra ou no mundo árabe - que renunciaram ao seu objetivo de libertação e enredaram-se nas políticas antipopulares inspiradas pelo FMI. Eles também se aproveitaram da crise e da decomposição da esquerda que se seguiu ao desmoronamento do "socialismo real" crise que enfraqueceu as identidades de classe e a idéia de unidade de todos os explorados, para além das clivagens étnicas ou confessionais. Isso vale menos para os países em que o nacionalismo de esquerda continua sendo uma força de oposição Curdistão, Timor Leste e Filipinas - ou, ainda que muito recentemente, em que chegou ao governo, como na África do Sul ou na Eritréia.

O caso da América Latina é um tanto diferente, pois encontramos, nessa região, poucos conflitos interétnicos, interconfessionais ou “comunalistas" - o que não significa dizer que o racismo e a exclusão social das comunidades indígenas ou negras não existam...

Encontramos igualmente na América Latina as duas forças do nacionalismo [acima referidas]. O clássico exemplo de nacionalismo reacionário é a

6 Inkhata: Inkatha Freedom Party (ou Partido da Liberdade Inkatha, também conhecido pela sigla IFP) é um partido político sul-africano (N. T.). 
ideologia "patriótica” dos regimes militares - como na Argentina, no Brasil, no Chile, nos anos 1970 e 1980 - geralmente dirigido contra o fantasma do "comunismo internacional" e seus "agentes subversivos" latino-americanos. Em nome da doutrina da segurança nacional, cada protesto social, cada movimento de esquerda era denunciado como sendo de "inspiração estrangeira" ou fundado nas "doutrinas exóticas opostas às nossas tradições nacionais".

Esse tipo conservador de nacionalismo de Guerra Fria fez uma ampla utilização dos símbolos nacionais (a bandeira, o hino nacional) e da retórica patriótica, mas aceitava, sem hesitação, a hegemonia dos Estados Unidos, a liderança norteamericano do "mundo livre”. Ele pode referir-se à geopolítica para reivindicar um papel subimperialista de hegemonia regional - como os militares brasileiros durante os anos 1970. Mas essa ambição muito raramente conduz a um conflito aberto com as potências ocidentais rivais, como no caso dos generais na guerra da Argentina contra a Inglaterra no que concerne às Ilhas Malvinas. O último exemplo - bastante caricatural - dessa atitude foram as gesticulações "nacionalistas" contra Estados Unidos da junta militar no Haiti e dos seus partidários macoutes.

O nacionalismo de tipo populista que alcançou seu apogeu no curso dos anos 1940 e 1950 peronismo na Argentina, aprismo no Peru, varguismo no Brasil - está em declínio e/ou reconciliou-se com o capital estrangeiro. O caso mais surpreendente é aquele do governo peronista do Presidente Menem que rompeu, sistematicamente, com todos os laços da tradição nacionalista do seu movimento e aplicou estritamente as orientações do FMI. Em alguns casos, como no México, a crise do governo populista (dirigido pelo Partido Institucional Revolucionário (PRI)) conduziu a uma ruptura e à formação de um novo partido. O Partido Revolucionário Democrático (PRD), dirigido por Cuhautemoc Cárdenas - filho do antigo Presidente Lázaro Cárdenas, quem, nos anos 1930, expropriara as companhias petrolíferas norte-americanas - tem por objetivo reatar os laços com a tradição nacionalista e anti-imperialista da revolução mexicana.

O combate contra a dívida externa e contra as políticas neoliberais impostas pelo FMI foi o principal eixo de mobilização dos sentimentos nacionais e das iniciativas anti-imperialistas na América
Latina, sob a forma de manifestações, greves, protestos e mesmo levantes. Graças às pesadas pressões para o pagamento (de resto, impossível) da dívida externa, o FMI e o Banco Mundial exercem um controle tal sobre as políticas econômicas e sociais dos países do continente - sem precedente desde o fim da colonização espanhola no século XIX - que suas independências são, freqüentemente, reduzidas a uma ficção. Os "conselheiros" e "peritos" das instituições financeiras internacionais ditam aos governos latino-americanos suas taxas de inflação, seus cortes orçamentários na educação e na saúde, suas políticas salarial e fiscal... As lutas populares contras essas formas extremas de dependência e contra o pagamento da dívida externa são movimentos não apenas nacionalistas, mas também anti-sistêmicos (para utilizar um conceito de Immanuel Wallerstein) por sua oposição à lógica da finança capitalista mundial. Elas também possuem um componente de "classe" em relação ao seu conflito com as elites dominantes locais - sempre prontas a respeitar rigorosamente as indicações do FMI e dos bancos.

Não é de admirar que em muitos países, como no Brasil, na Bolívia, no Peru e no México, o movimento operário, os sindicatos, os partidos de esquerda sejam os que levam adiante o combate contra a dívida externa: libertação nacional e libertação social estão estreitamente ligadas na consciência dos setores mais ativos do movimento. Lula, o dirigente do Partido dos Trabalhadores (PT) brasileiro, defendeu uma moratória da dívida e uma consulta popular sobre a utilização do dinheiro emprestado (nomeadamente pelo regime militar que governou o país de 1964 a 1985). Ele também propôs uma iniciativa conjunta dos endividados, considerando que nenhum desses países é poderoso o suficiente para sozinho enfrentar os credores.

Em que medida um país isolado - mesmo que ele seja relativamente desenvolvido, como o Brasil ou o México - pode rejeitar a ditadura do Banco Mundial e romper o jugo da dominação imperialista? A integração latino-americana pode constituir-se em uma alternativa aos planos norte-americanos de livre comércio? Como conquistar a libertação nacional e social em um país subdesenvolvido sem o apoio econômico e social de uma potência como a União Soviética? Qual é o peso das contradições entre a Europa, os Estados Uni- 
dos e o Japão e em que medida elas podem ser exploradas pelos movimentos emancipadores dos países periféricos?

Essas questões e outras similares - às quais não é fácil responder - estão, neste momento, sendo discutidas na América Latina e nas outras regiões do Sul. Elas mostram que a libertação nacional continua sendo uma questão vital na periferia do sistema, mas também que as soluções puramente nacionalistas têm um valor limitado: talvez a necessidade de uma estratégia internacionalista seja hoje melhor percebida que no passado.

O exemplo de Cuba parece mostrar que um país independente pode, ao menos durante um período limitado, sobreviver a um bloqueio norteamericano, a um boicote das instituições financeiras e à ausência de apoio da ex-URSS. Mas o futuro de Cuba dependerá em longo prazo dos desenvolvimentos do restante da América Latina.

No curso dos últimos anos, as diferentes forças socialistas, nacionalista e anti-imperialistas da América Latina - incluindo, entre outras, o PT brasileiro, a FSLN (Frente Sandinista de Libertação Nacional) nicaragüense, a FMLN (Frente Farabundo Martí pela Libertação Nacional) salvadorenha, o PRD mexicano, o Lavalas do Haiti e o Partido Comunista Cubano - sentiram a necessidade de uma coordenação internacional (ou, ao menos, regional) e decidiram constituir uma frente unida, pluralista e democrática, conhecida como Fórum de São Paulo, que se encontra anualmente para discutir perspectivas comuns.

Durante a primeira conferência do Fórum em São Paulo, em 1990 -, um documento de importância histórica foi adotado, o qual apresenta as linhas de força de uma estratégia de libertação nacional para a América Latina. Logo de início, ele rejeita as propostas de "integração americana" apresentadas pelos Estados Unidos, denunciandoas como uma tentativa "de abrir completamente nossas economias nacionais à competição desleal e desigual com o aparelho econômico imperialista, submetendo-as inteiramente à sua hegemonia e destruindo suas estruturas produtivas por meio da integração em uma zona de livre troca liderada, dirigida e organizada pelos interesses econômicos norte-americanos". O documento opõe a essa proposta hegemonista uma nova concepção de unidade e de integração continentais, fundada na so- berania e na autodeterminação da América Latina, na recuperação da sua identidade cultural e histórica e na solidariedade internacional entre seus povos. "Isso pressupõe a defesa do patrimônio latino-americano, o fim da fuga e da exportação de capitais, uma política comum e unificada face ao flagelo de uma dívida impagável, bem como a adoção de políticas econômicas em benefício das maiorias, capaz de combater a situação de miséria na qual vivem milhões de latino-americanos" (FORO DE SÃO PAULO, 1990, p. 3; Inprecor, 1990, p. 6).

Além do nacionalismo anti-imperialista, um outro tipo de nacionalismo emancipador desenvolveu-se na América Latina ao longo dos últimos anos: o movimento dos indígenas pelos seus direitos. O debate em torno dos 500 anos do "descobrimento" das Américas e o prêmio Nobel concedido a Rigoberta Menchu [em 1992] deram uma visibilidade maior às lutas indígenas pela defesa das suas comunidades, das suas terras e da sua cultura nacional contra a opressão das oligarquias de origem hispânica ou mestiça.

Esses movimentos indígenas, associações ou partidos políticos (como o movimento Tupac Katari, na Bolívia) em geral não se limitaram a um grupo étnico (quechuas, aymaras, maias etc.), mas unificaram todas as comunidades indígenas de cada país. Eles desenvolvem uma crítica radical da civilização ocidental e dos seus valores - a propriedade privada, o individualismo, a mercadoria - em nome das tradições indígenas pré-capitalistas e/ou pré-colombianas e de sua cultura comunitária.

Enquanto algumas organizações possuem um forte componente étnico e reivindicam a restauração das velhas nações ou impérios indígenas, a maior parte desses movimentos luta pelo reconhecimento dos direitos nacionais e culturais dos povos indígenas, em coalizão com outros grupos ou classes oprimidas. Um exemplo importante é o movimento intitulado "Quinhentos anos de resistência indígena, negra e popular” que se desenvolveu, em 1990-1992, em toda a América Latina, contra as comemorações oficiais dos 500 anos... Mas o exemplo mais espetacular é, sem dúvida, a insurreição zapatista do Chiapas, fundado sobre as reivindicações nacionais das comunidades indígenas e sobre sua luta pela terra. Encontramos nos documentos do Exército Zapatista de Libertação Nacional (EZLN) uma fusão, única 
em seu gênero, entre as tradições da revolução mexicana, a cultura maia dos indígenas do Chiapas e as idéias marxistas da esquerda latino-americana.

Durante uma reunião da Convenção Nacional Democrática, convocada em novembro de 1994 pelos zapatistas em Chiapas, muitas organizações indígenas mexicanas adotaram uma resolução, que é um dos mais notáveis documentos - nunca antes produzido - sobre a questão nacional indígena na América Latina. Partindo da constatação de que os indígenas mexicanos foram, ao mesmo tempo, desapossados das suas terras e da sua identidade, o texto propõe a substituição do sistema político atual, fundado sobre uma estrutura estatal centralizada, intolerante e autoritária, por um Estado de autonomias que possibilite o respeito ao pluralismo e a participação dos povos indígenas na vida democrática. Para as regiões habitadas por vários povos ou grupos socioculturais, o documento propõe, por meio de uma livre decisão dos interesses, "a possibilidade de viver em conjunto na unidade e na diversidade, na igualdade e no respeito mútuo. Isso significa a criação de regiões multiculturais ou multi-étnicas”. A autonomia é uma aspiração secular que se exprime na vida cotidiana das comunidades indígenas, nas suas formas de organização e de produção: trata-se de transformar essas práticas em elementos constitutivos do sistema político mexicano instituindo-se um novo nível de poder regional em todo o país. Por outro lado, os indígenas mexicanos insistem sobre o fato de que seu projeto de autonomia "nada tem a ver com o separatismo, que é para nós, povos índios, uma idéia estéril” (MEXIQUE: NOUVELLE RELATION, 1995).

Evidentemente, existem diferenças notáveis entre as nações indígenas de países como a Guatemala, o Peru ou a Bolívia, nos quais elas constituem a maioria da população, e as pequenas tribos que sobrevivem na região amazônica. Enquanto no primeiro caso a luta nacional está intimamente ligada à luta social e à questão agrária (luta pela terra), no segundo, trata-se mais de uma luta pela proteção face à lógica etnocida da "civilização".

A resistência dos sindicalistas, ecologistas e tribos indígenas contra o desenvolvimento destruidor do agronegócio pode conduzir a certas ações conjuntas, tais como aquelas que ocorrem na Amazônia, com a constituição de uma Confederação dos Povos da Floresta, por meio da iniciativa do dirigente sindical, militante do Partido dos Trabalhadores e ecologista, Chico Mendes - assassinado pouco depois pelos proprietários de terra.

Uma terceira forma de nacionalismo progressista na América Latina é o nacionalismo negro, que se desenvolveu, sobretudo, nos países do Caribe. Inspirado pela tradição das insurreições dos escravos - a revolução haitiana de Toussaint Louverture em 1791 - e pelo Black Power ${ }^{7}$ americano, esse movimento ainda não encontrou sua expressão política de massa, sendo suas principais manifestações mais religiosas ou culturais. Essa também é a situação do Brasil, onde a resistência cultural negra adquire, sobretudo, uma forma religiosa por meio do desenvolvimento da umbanda, um culto sincrético composto de elementos africanos e cristãos.

O nacionalismo, mesmo nas suas formas mais progressistas, não pode ultrapassar certos limites. Do ponto de vista marxista - que é aquele que inspira o autor deste artigo - os grandes problemas da nossa época são internacionais e não podem ser resolvidos no âmbito de uma única nação: isso vale também para questões decisivas como a discrepância crescente entre o Norte e o Sul, a crise do capitalismo mundial ou a ameaça da catástrofe ecológica sobre o planeta. Como visão de mundo internacionalista, o marxismo contrariamente às suas múltiplas contrafrações nacional-burocráticas - tem a vantagem de uma posição universalista e crítica que cria a possibilidade de escapar das paixões e da embriaguez da mitologia nacionalista. Mas isso não significa que ele pode ignorar impunemente a importância das culturas nacionais ou a legitimidade da luta pelos direitos nacionais democráticos. Em outros termos, seu universalismo não pode permanecer abstrato, fundado sobre a simples negação das particularidades nacionais, mas deve tornar-se um verdadeiro universal concreto (Hegel), capaz de incorporar, sob a forma de uma síntese (Aufhebung) dialética, toda a riqueza do particular, todos os tesouros culturais da diversidade humana.

Graças ao conceito de imperialismo, o marxismo pode evitar as armadilhas do falso universalismo eurocêntrico (ou "ocidental”), que pretende impor a todos os povos do mundo - e em particular, àqueles da periferia -, sob o manto

\footnotetext{
7 Em inglês: “Poder Negro” (N. R.).
} 
da “civilização”, a vida burguês-industrial moderna: propriedade privada, economia de mercado, expansão econômica ilimitada, produtivismo, utilitarismo, individualismo possessivo e racionalidade instrumental. Sem falar da pseudocultura moderna, despejada dia e noite por meio dos meios de comunicação ocidentais em escala global, pelos donos da sociedade do espetáculo capitalista, atropelando, no caminho, as culturas autóctones.

Isso não significa que os marxistas devam ignorar o valor universal de certas conquistas da cultura européia desde 1789, como a democracia, as liberdades individuais, a igualdade perante a lei e os direitos dos homens - longe de serem efetivamente alcançadas nas sociedades modernas "realmente existentes". Trata-se, pois, de recusar o falso dilema entre um pretendido universalismo "ocidental" e um relativismo abso- luto que se recusaria a julgar criticamente práticas inumanas - como, por exemplo, as mutilações sexuais - sob o pretexto de respeitar identidades culturais ou nacionais.

Para o marxismo, o valor universal mais importante é a libertação dos seres humanos de todas as formas de opressão, dominação, alienação e degradação. É esse um universalismo utópico, ao contrário dos universalismos ideológicos que fazem apologia do status quo capitalista ocidental como a cultura humana universal alcançada, o fim da história, a realização do espírito absoluto ou a forma última de modernidade. Somente um universalismo crítico e concreto desse tipo, que enxerga o horizonte de um futuro emancipado, é capaz de ultrapassar tanto os nacionalismos limitados quanto os culturalismos míopes como os etnocentrismos e os colonialismos.

\title{
NACIONALISMOS DOS TERCEIROS MUNDOS PARA UM DEBATE, EM RESPOSTAA MICHAEL LÖWY ${ }^{8}$
}

\author{
Michel Cahen
}

O artigo de Michael Löwy, "Nacionalismos do Sul”, publicado no n. 144, do inverno de 19951996, da revista Critique communiste, abre um debate necessário, mas que, a meu ver, não rompe com algumas categorizações contestáveis - e mesmo eurocêntricas.

\section{ALIBERTAÇÃO DE TODAS AS FORMAS DE OPRESSÃO}

Isso não poderia ocultar um acordo fundamental sobre muitos pontos: em primeiro lugar, a reafirmação do conceito de imperialismo, que alguns atualmente diluem, por meio de uma prática muito freqüente, no oceano de uma "mundialização" em voga, que seria, de certa maneira, neutra (naturalmente, a manutenção do conceito de imperialismo não significa que a mundialização não possua

8 O original deste artigo data de 3 de abril de 1996 e foi publicado em Cahen (1996-1997), mas esta tradução foi realizada a partir da versão publicada na forma de capítulo em Cahen (1999, p. 127-143) (N. T.). um lugar, mas que ambos são dimensões diferentes, mesmo que ligadas, da nova fase do capitalismo). Em segundo lugar, M. Löwy escreve visivelmente para obstaculizar a tendência muito freqüente entre os marxistas de enxergarem somente a "luta de classes” e, nesse sentido, de desvalorizarem todas as outras formas do movimento social, suspeitas a priori de serem, no melhor dos casos, menos portadoras na perspectiva emancipadora e, no pior, manipuladas pelo imperialismo: é esse o caso em particular da etnicidade política e dos nacionalismos que ela produz. O marxismo, desse modo, transforma-se rapidamente em um economicismo de esquerda e, nomeadamente na França, sucumbe às influências jacobinas fetichistas do Estado não somente unitário mas, sobretudo, uniformizador. Nesse sentido, devo aplaudir quando Löwy afirma que o universalismo dos marxistas não seria o de identificar-se com uma negação das particularidades nacionais, mas “[...] deve tornar-se um verdadeiro universal concreto (Hegel) capaz de incorporar, sob a forma de uma síntese 
(Aufhebung) dialética, toda a riqueza do particular, todos os tesouros culturais da diversidade humana. [...] O valor universal mais importante é a libertação dos seres humanos de todas as formas de opressão [...]" (LÖWY, 1995-1996, p. 81; sem grifos no original).

Ora, algumas formas de opressão, ainda que integradas global e indiretamente ao capitalismo, podem ser-lhe anteriores e não diretamente classistas - o que, no entanto, de maneira alguma significa que elas não possam ser integradas ao programa libertador de um movimento classista, na condição de que esse movimento saiba compreender seus fundamentos e suas formas de expressão.

Portanto, deve ficar claro de uma vez por todas que afastamos a incontestável tendência presente em Marx - e mais ainda em numerosos epígonos - de uma visão linear da história que iria do "menor" (tribo antiga) à nação medieval, depois à nação mercantil do capitalismo a ser ultrapassada graças ao "cadinho mundial" do capitalismo, dos reagrupamentos continentais e mundiais em direção à nação mundial, isto é, à não-nação mundial uniforme ${ }^{9}$. O que deve ficar é claro que a marcha da humanidade não é ir do menor ao maior, mas em direção a uma dialética de uma construção-desconstrução permanente dos níveis de identidades ligados entre si; o surgimento de níveis mais amplos (um sentimento nacional europeu, por exemplo) de maneira alguma significa o desaparecimento de níveis mais restritos (sentimento nacional por um país, por exemplo), podendo mesmo revificá-los. O "maior” não é, automaticamente, mais progressista que o "menor". A nação, enquanto for portadora dos sentimentos íntimos das pessoas, não pode ser "ultrapassada”.

Inter-nacionalismo não é, de modo algum, antinacionalismo. Podemos tornar nossa a frase de Marx, contanto que ela esteja inteira: "Proletários de todos os países, nações e povos oprimidos, uni-vos!” (MARX \& ENGELS, 2008 [18471848], p. 25; sem grifos no original) - e, mais ainda, meditar sobre o título que o escritor portu-

9 Um exemplo típico dessa visão linear e paternalista, hostil aos “pequenos povos”, é veiculado por Samir Amin, para quem toda luta de libertação - dentro de um Estado independente - não é mais que manobra imperialista com vistas a destruir os "grandes estados" em benefício dos "pequenos". guês Miguel Torga deu a uma conferência que ele proferiu em São Paulo e no Rio de Janeiro, em 14 e 16 de agosto de 1954, a imigrantes portugueses originários da altiva e particularista região do TrásOs-Montes: "O universal é o local menos as paredes” (TORGA, 1994).

\section{NACIONALISMO VERSUS MUNDIALIZA- ÇÃO: É TÃO SIMPLES ASSIM?}

O mal-estar surge em muitas ocasiões. Retomemos o fio da exposição de Löwy. Desde o início, ele afirma que a "escalada de nacionalismos" é "ao menos em parte" uma reação à “mundialização da economia”. Formulado nesses termos, isso não diz muita coisa, pois tudo depende do que Löwy quer dizer por "ao menos em parte”. O nacionalismo seria apenas o privilégio dos desassistidos do planeta? Será que Löwy retoma a afirmação de Bourgeot (1994), segundo a qual “os povos felizes não possuem etnia”? Como compreender, nesse caso, o nacionalismo da Catalunha, região economicamente dominante na Espanha? Ou da Escócia, ainda mais afortunada? Ou da região da Flandres belga, onde o separatismo é alimentado pelo desenvolvimento econômico mais desvencilhador em relação à Valônia, anteriormente dominante? É necessário recuar na história: se remontamos a apenas século e meio, veremos que o período atual (possuindo em seu interior conjunturas diversas) não engendra mais a tensão nacionalista como as precedentes. A mundialização sempre existiu no Mundo Antigo e, a partir das grandes descobertas, existiu para as Américas ${ }^{10}$. O que é novo é que numerosas formações sociais do Terceiro Mundo, que eram apenas indiretamente submissas ao modo de produção capitalista (MPC), hoje são-no diretamente, estando violentamente integradas ou, talvez, abandonadas à destruição pura e simples, à anomia social, enquanto o crescimento demográfico prossegue e multiplica na mesma escala os efeitos dessa submissão direta.

O incontestável aumento de novos nacionalismos - não necessariamente numerosos - na atual conjuntura não é produto da mundialização, mas, antes de tudo, do fracasso dos nacionalismos de Estado hostis às etnicidades realmente existentes, dos regimes laicos radicais profundamente paternalistas e opressores no que concerne às re-

10 Nota do autor (2008): não escreveria mais isso hoje: a mundialização não é simplesmente sinônimo de "expansão” ou “internacionalização mercantil”. 
lações sociais não diretamente ligadas ao modo de produção capitalista, em relação às culturas populares (a Argélia, a Angola, o Moçambique "progressistas” não são muito diferentes, sob esse ponto de vista, da Indonésia “reacionária”). A não assunção das aspirações identitárias, combinadas com o fracasso total econômico e social, provoca o que acima dissemos ${ }^{11}$.

Löwy tem razão ao precisar que os nacionalismos são "ora democráticos e emancipadores”, ora "regressivos, intolerantes, agressivos" e que a fronteira entre essas duas tendências é móvel. Mas o que os empurraria mais em um sentido que em outro? Unicamente a configuração social e econômica? O que está completamente ausente no artigo de Löwy é que essa mobilidade depende, nomeadamente, da atitude das correntes operárias e revolucionárias no que lhes concerne! Nomeadamente, foi a recusa bolchevique de tomar a direção do movimento pela independência dos povos da Ásia Central que os levou aos mencheviques ou aos russos brancos. Se, a um camponês de etnia macua que trabalha nas grandes plantações do norte de Moçambique (e, portanto, "objetivamente" proletarizado), que se ressente profundamente da opressão e do desprezo paternalista de um Estado moderno dominado por grupos étnicos do Sul, o militante progressista responde apenas que tudo isso não é mais que falsa consciência tribal e identidade atrasada e que nosso camponês é, "na verdade", um proletário rural, ele tem certeza de que os verdadeiros reacionários saberão não lhe negar a sua "identidade retardatária” ao construir para si uma base social para as suas manobras políticas.

A etnicidade política (sendo o nacionalismo uma das suas formas) não é nem reacionária nem progressista. Simplesmente, ela é. A etnicidade concerne ao imaginário, ela é um sentimento. Ser

\footnotetext{
11 Ë por esse motivo, mesmo que eu não concorde necessariamente com todas as suas conclusões, que aprovo a questão que formula a militante Luiza Toscane, resumida pelo título do seu livro: L'Islam, un autre nationalisme? [O Islã, um outro nacionalismo? - cf. TOSCANE, 1995 (N. T.)], questão que, entre os trotskistas, passou quase despercebida. Assistimos a uma nova produção de um sentimento nacional, baseada na opressão social de uma comunidade de origem pluriétnica, delineada por uma religião? Que existam tendências nesse sentido parece-me incontestável; a divergência poderia vir da probabilidade de realização dessas tendências, que podemos aceitar ou recusar.
}

francês não é ser nem reacionário nem progressista e o amor ao queijo camembert não é nem de direita nem de esquerda. Mas enquanto expressão do desejo de uma assunção coletiva do seu destino por uma comunidade subjetiva, a etnicidade pode ser um fator de libertação. Naturalmente, isso dependerá das forças sociais que a exprimirão, mas tão amplamente como a direção política que tomará a sua direção. No Terceiro Mundo, pois, combinar-se-ão as clássicas lutas de classes e o fato de que comunidades inteiras, interclassistas por definição, são globalmente oprimidas. Na consciência popular sábio será quem conseguir adivinhar o que se alcançará primeiro: a expressão da consciência de classe ou a consciência comunitária. E será mais freqüentemente, em uma mistura indissociável dos dois, que o nacionalismo terá a forma da tomada de consciência de classe ${ }^{12}$.

\section{OS PROLETÁRIOS SÃO APENAS PROLE- TÁRIOS?}

Não devemos, de maneira alguma, ficar embaraçados por fórmulas do tipo: "Os proletários não têm pátria!”, pois elas são... totalmente justas! Os patrões, eles também não possuem pátria. Mas o movimento social não é feito somente de classes enquanto categorias econômico-sociais. Um indivíduo nunca possui - eu reafirmo: nunca - uma identidade única. Um proletário é proletário, mas ele será também, por exemplo, católico e basco. E, enquanto basco, ele possui uma pátria, como o seu patrão, uma pátria que pode ser globalmente oprimida. No entanto, no movimento social, não são as classes econômico-sociais que se exprimem diretamente, mas as forças sociais que combinam as "classes para si" com outros níveis identitários. Querer isolar e superdimensionar exclusivamente a consciência de classe, hostilizando os outros fatos de consciência, é obrigar o indivíduo real a uma escolha impossível; é ser totalmente sectário em relação

12 No País Basco espanhol, se o ETA (Pátria Basca e Liberdade) (da sua VI ${ }^{\mathrm{a}}$ Assembléia) trotskista de 1973 perdeu tudo foi porque ele, por "classismo puro", condicionou a luta pela independência à luta pelo socialismo na Espanha: isso está manifestamente expresso na sua mudança de nome, de ETA para LKI - Liga Komunista Irauliza (Liga Comunista Revolucionária). Mas a opressão capitalista era, bem ou mal, ressentida primeiramente como espanhola e a separação da Espanha era, pois, a condição da expressão da consciência de classe. Sobre todos esses aspectos, permito-me remeter ao meu livro (CAHEN, 1994). 
ao movimento das massas, em particular no Terceiro Mundo, onde as formações sociais, historicamente residuais, mas reunindo ainda centenas de milhões de pessoas, possuem ainda uma relevância [prégnance] política considerável ${ }^{13}$.

\section{NACIONALISMO DE ESTADO E ETNICI- DADE POPULAR}

Penso que as categorizações habituais de nacionalismos, se elas permanecem válidas, não são, de fato, suficientes para exprimir a realidade dos movimentos etnonacionais nos terceiros mundos. Essas categorizações habituais dizem respeito ao "nacionalismo emancipador” (a Polônia antes da I Guerra Mundial, a Irlanda, o Curdistão, os movimentos berberes, o movimento anti-apartheid na África do Sul, o nacionalismo revolucionário boliviano no início dos anos 1950 etc.) e ao "nacionalismo opressor" (o pan-germanismo, o expansionismo russo-soviético, o pan-sinismo ${ }^{14}$, o nacionalismo amhara etc.).

13 Sobre esse assunto, é necessário reafirmar a pertinência da noção de “Terceiro Mundo”, que, segundo Löwy, nada mais significa após o desaparecimento do "Segundo Mundo", dito “socialista”. Não entrarei aqui no debate - necessário - acerca da heterogeneidade dos estados capitalistas da periferia. No entanto, a noção de "Sul", atualmente em voga, é ainda pior. Dito rapidamente, "Terceiro Mundo" [Tiers monde no sentido de "Mundo Terço" e não Troisième Monde - N. T.] jamais significou que ele é "terceiro" em relação ao "segundo" (ex-União Soviética): foi uma analogia recente (de 1956) em relação ao Terceiro Estado da Revolução Francesa, que era, com certeza, a "terceira ordem" abaixo do clero e da nobreza, mas no sentido de "a Ordem dos Outros”, dos não-privilegiados, e cujo sentido político foi, imediatamente, a afirmação da imensa maioria oprimida da população face ao conjunto da classe aristocrática (Sieyès). Certamente, “Terceiro Mundo” não é um conceito puro de classe e o fato de que ele seja globalmente oprimido não significa que os habitantes do "Norte" sejam globalmente responsáveis pela situação que lhe é imposta, como pensam alguns terceiromundistas. Mas esse vocábulo tem, ao menos, o mérito de apontar a realidade da opressão, enquanto as simples noções cardinais ("Norte", "Sul” etc.) fazem parte desse movimento de interdição de palavras que se seguiu ao desmoronamento do stalinismo senil: não mais o "capitalismo”, mas a “democracia liberal”! Não mais o "imperialismo", mas a escolha de "Norte" ou de “mundialização”! Não mais o “Terceiro Mundo”, mas o "Sul”! Não mais "luta de classes”, mas, no melhor dos casos, a "fratura social” etc. Agradeço, pois, à Actuel Marx por ter intitulado um dos seus recentes volumes de "O imperialismo" (Actuel Marx, 1995)!

14 Diz respeito ao expansionismo nacionalista chinês (N. T.).
No entanto, elas não sublinham suficientemente uma diferença essencial: o nacionalismo polonês, a luta chinesa antinipônica, os patriotismos cubano ou vietnamita exprimem, politicamente, nações (ou seja, sentimentos nacionais) que já existem. Eles são nacionalismos produzidos por um movimento de massa, mesmo que, inevitavelmente, a elite exerça seu papel de intelectual orgânico coletivo. O "nacionalismo" moçambicano é um projeto de nação. Bem entendido, há casos intermediários, mas a diferença desses casos não é menos pertinente. A luta anticolonial, seja a da Argélia ou da Guiné contra o imperialismo francês, da Índia ou do Quênia contra o imperialismo inglês, de Angola ou de Moçambique contra o imperialismo português ou da Indonésia (que não deveria ser reduzida a Java) contra o imperialismo holandês, possui um fundamento de massa - a luta contra o opressor estrangeiro para a obtenção da sua partida. Mas esse tipo de luta não cria, ipso facto, uma nação.

É totalmente ilusório - e isso é aceitar como líquidas e certas as propagandas oficiais das direções nacionalistas - acreditar que uma luta armada de dez ou 15 anos produz uma nação. Toda luta de libertação produz efeitos unificadores, mas também induz efeitos de guerra civil. O povo colonizado não é homogêneo e alguns dos seus segmentos - por motivos históricos bem explicáveis - consideram outros segmentos como, talvez, piores que o colonizador: por exemplo, devido ao tráfico de escravos na África conduzido por alguns estados africanos que buscavam escravos em outros estados africanos, essa lembrança é ainda viva. A luta de libertação provoca o surgimento de novas repúblicas e de novas cidadanias; mas o hábito de viver em uma mesma República (Senegal, Moçambique etc.) não cria um sentimento nacional profundo e a relevância [prégnance] das etnicidades mais locais (mas às vezes bastante vastas!) permanece amplamente dominante! Nada podemos compreender das guerras civis angolana e moçambicana se não apreendemos a importância de que esse é um caso de Estado sem nação

Estado sem nação, mas Estado nacionalista15: o movimento social foi incitado ao nacionalismo

15 Nota do autor (2008): hoje em dia, já não utilizo o conceito de nacionalismo para exprimir a ideologia de um Estado, cujo desejo é criar uma nação. O nacionalismo, de qualquer modo, exprime uma nação. Chamo hoje o projeto elitista de criar uma nação a partir de um Estado de “nacionismo” (cf. CAHEN, 2006). 
por uma elite europeizada, formada à imagem e à semelhança dos estados-nação europeus (jacobinos ou não). Trata-se de um nacionalismo induzido, elitista, antidemocrático, cuja primeira e principal decisão foi a de aceitar a intangibilidade das fronteiras coloniais. Esse nacionalismo não é somente uma idéia; ele é uma política econômica, social e cultural cotidiana; ao mesmo tempo em que oprime as línguas maternas, estigmatiza de "feudalismo" e "tribalismo" as manifestações culturais das sociedades, ele inevitavelmente concentra os investimentos na capital e nas empresas de alta concentração de capital fixo, visto que a modernidade não pode existir senão como concreto ${ }^{16}$, pesadamente mecanizada, produtora de divisas conversíveis e exprimida em uma das línguas coloniais.

Contudo, esse nacionalismo de Estado expressa-se em um Estado que absolutamente não possui, por exemplo, a força aglutinadora da III República francesa. Ele opera no seio de uma economia de mercado sem mercado ou no seio de um mercado não enquadrado pela legalidade do Estado (economia dita informal), mesmo se as pessoas do Estado nele estejam presentes a título familiar. Esse nacionalismo estatista é opressor das etnias sem, contudo, produzir um mercado nacional à altura do capitalismo da época de Marx. Ele provoca, pois, fortes reações étnicas que tentam instrumentalizar os grupos sociais poderosos, mas que, na sua totalidade, são reações anti-estatais. Contrariamente à previsão de Senghor - "Na África, o Estado precedeu a nação” -, esse nacionalismo, por fim, destrói o Estado. Eis também porque as direções revolucionárias deveriam apoderar-se do ressentimento étnico na luta contra o Estado capitalista da periferia.

\section{LUTAS DE LIBERTAÇÃO... NACIONAL?}

Permanecemos prisioneiros das palavras. Dessa maneira, falamos de "lutas de libertação nacional” no Terceiro Mundo, enquanto, muitas vezes, a nação não existe e essas lutas sociais são lutas anticoloniais. Falamos de estados-nação do Terceiro Mundo - e mesmo do seu "fracasso" -, ao passo que não faz nenhum sentido falar de Estado-nação quando a nação não existe; ao passo que

16 Nota do autor (2008): isto é, um Estado que prefere copiar o modelo da cidade ocidental com seus grandes edifícios de concreto a assentar-se sobre os materiais locais. se trata de estados nacionalistas ("nacionalista” no sentido de "para a criação e/ou imposição da nação").

Reproduzimos aqui um forte eurocentrismo: a analogia legitimadora com as lutas de libertação nacional na Europa do século XIX e do início do século XX. O stalinismo também passa por aqui. Assim, "luta de libertação nacional” tornou-se um sinônimo legitimador de etapa da revolução burguesa. O paradoxo é qualificarmos de "libertação nacional” os regimes de partido único "de esquerda”, sustentados pelos países do Leste, que ferozmente se construíram contra as etnias, contra as nações de fato presentes no interior do espaço definido pelas fronteiras coloniais, projetando uma "nação" inventada, que não corresponde a nada de popular, projeção paternalista, às vezes exprimida pelo jargão maoísta de "homem novo".

Löwy sublinha o fracasso desses "governos nacionalistas 'de esquerda' ou laicos, por exemplo, na África negra ou no mundo árabe que renunciaram os seus objetivos de libertação e enredaram-se nas políticas antipopulares” (LÖWY, 1995-1996, p. 78). É necessário ater-se ao detalhe de quais objetivos de libertação trataram-se: não podemos comparar um nacionalismo desturiano $^{17}$ na Tunísia ou baasista ${ }^{18}$ na Síria e no Iraque com a orientação inicial de uma Frente Nacional de Libertação (FNL) argelina ou de um Partido Socialista Iemenita (PSY), tendo estes realmente experimentado processos (incompletos) de revolução permanente. Mas é necessário compreender que, tanto em um caso como no outro, uma das razões pelas quais esses partidos constroem estados burgueses (e, mais freqüentemente, ditatoriais) da periferia é que, já de início, eles possuem uma visão paternalista, burocrática e tecnocrática do desenvolvimento, uma idéia de rápida construção e imposição da "nação moderna" de tipo europeu, que justamente corresponde ao imaginário dos segmentos da elite no poder. No momento da independência, a nação

17 Relativo ao Partido Socialista Desturiano (PSD) que tomou o poder quando da independência da Tunísia, em 1956 (N. T.).

18 O Partido Baas chegou ao poder na Síria em 1963 e nele permaneceu até 1966, retomando-o em 1970 e nele permanecendo até os dias de hoje; chegou ao poder no Iraque em 1963, perdendo-o no mesmo ano e retornando-o em 1968 até 2003 (N. T.). 
árabe é imposta aos berberes da Argélia (nomeadamente por meio da arabização), ao mesmo tempo em que, quaisquer que sejam os discursos, o essencial dos investimentos públicos destina-se às empresas de alta concentração de capital fixo. Esse é o mesmo imaginário nacional elitista da etnia dominante que, tendo sabido conquistar o Estado moderno, exprime-se sob essas facetas aparentemente diferentes.

\section{ETNICIDADE E TRIBALISMO}

Gerações de marxistas cresceram com a equação "tribalismo = reação" na cabeça. É necessário constatar que Löwy não rompe verdadeiramente com esse ponto de vista, somente citando o "tribalismo" no momento em que se refere aos movimentos pró-sul-africanos e aos movimentos racistas. Contudo, não esqueçamos que o apoio da Internacional Comunista à luta de libertação do Rife marroquino teve como objetivo a "República das tribos confederadas”. Um objetivo desse tipo seria, hoje, perfeito para o Afeganistão e para muitos outros estados do Terceiro Mundo, mas ninguém mais de esquerda ousa falar disso. As tribos rifenhas dos anos 1920 não eram, contudo, mais perfeitas que as de hoje.

Mas que é uma tribo? Nós não empregamos essa palavra com o mesmo sentido que o dos anglo-saxões (sua tribe significa, de fato, “etnia”, mas sua ethnicity engloba, freqüentemente, a questão, impensável na França, das racial relations). Eu falaria de tribo no caso de uma organização política para-estatal (ou pré-estatal), uma chefatura, se assim quisermos, bastante estabilizada, que não deve ser confundida com a comunidade imaginária esquadrinhada pelo sentimento de etnicidade. Uma tribo pode calcar uma etnia, mas isso não é inelutável. Na África, não há mais muitas tribos desde que a conquista colonial aniquilou-as (clãs somalis, alguns segmentos etíopes, Estado regional do Kwazulu etc.), mas há muitas etnias (algumas das quais surgiram durante a colonização). Assim definidas, excetuando todos os fantasmas, facilmente concebemos a possibilidade histórica do tribalismo revolucionário, caso as chefaturas efetivamente tomem a direção de uma luta emancipadora e conheçam um processo de radicalização (CAHEN, 1991). Sem dúvida, neste momento, elas encontrarão à sua frente - ao redor do imperialismo - os "regimes nacionalistas" de esquerda ou de direita que as denominarão de separatismo, de feudalismo e de banditismo
(Casamansa, Sudão do Sul, Cabinda, Irian Ocidental $^{19}$, Caxemira, Tchechênia...).

O fato de Ruanda "ser apenas uma referência identitária de tipo (real ou fictício) ‘étnico’ que serviu de ideologia a um dos piores crimes contra a humanidade das últimas décadas" (LÖWY, 19951996, p. 78) não significa, de modo algum, que a etnicidade seja responsável pelo massacre. Podemos perguntar-nos qual é o objetivo de Löwy ao oferecer esse argumento: referências identitárias "de fato étnicas" têm estado na base das lutas de libertação (sendo o seu melhor exemplo atual dessas lutas de libertação o Chiapas). Mesmo a crítica do "nazismo tropical” (segundo a contestável expressão do historiador dos Grandes Lagos, JeanPierre Chrétien) foi surpreendentemente contraditória: segundo alguns, trata-se de tentar provar que as “etnias” não existiam, já que hutus e tutsis falavam a mesma língua, possuíam a mesma cultura etc., "prova" que não os impediram de denunciar a colonização belga, culpada por estar na origem dessas... etnias. Segundo outros, a etnicidade de fato existiu como responsável do problema.

Apesar da enormidade do desastre humano, o caso dos ruandeses e dos burundis é, a meu ver, mais uma exceção: é evidente que a lenta decomposição da ligação social entre as castas (e de modo algum entre as etnias) diferenciadas, a partir dos anos 1920, pela natureza da sua relação com a terra, com a criação de animais e, portanto, com o Estado, combinada com uma considerável pressão demográfica e fundiária - agravada a partir da independência -, somada à crise do Estado moderno - na altura do ajuste estrutural a partir do fim dos anos 1960 -, tendo, como pano de fundo, as rivalidades entre os imperialismos francês e inglês, provocaram o drama que conhecemos. No entanto, isso nada tem a ver, exceto em nossos fantasmas, com a produção política da etnicidade propriamente dita. Ao desencadear fenômenos mórbidos contra ela própria (Gramsci), a sociedade implode certamente por motivos sociais, contudo obedecendo - obviamente - a linhas de clivagens bem conhecidas de todos e, portanto, disponíveis na sociedade e no imaginário do matador cotidiano - nesse caso, linhas de clivagens de castas.

19 A ex-colônia holandesa de Papua Ocidental (antiga Irian Jaya) passou para o controle de Jacarta em 1963 (N. T.). 
Não se trata de substituir um nome por outro - "etnia” por "casta" -, mas de compreender que temos diante de nós fenômenos sociais diferentes. Que eu saiba, os sangrentos conflitos entre hindus e muçulmanos durante a criação do Paquistão não são da mesma natureza que o massacre dos tutsis pelas milícias hutus. Hutus e tutsis fazem (faziam?), de fato, parte da mesma etnia ou nação ruandesa e o massacre seguiu as linhas de um imaginário social (social "real” ou "fictício”, como diria Löwy: camponeses e criadores de animais) e não étnico. Se é bastante evidente que a crise da Iugoslávia também está ligada a problemas sociais, a comparação entre os massacres interétnicos eslavos do Sul e aqueles entre os hutus-tutsis é completamente abusiva. Contudo, ela incomoda a consciência cidadã democrática européia, produtora de conceitos e, por isso, propensa, ao mesmo tempo, à analogia.

É verdade que essa simultaneidade não é, aparentemente, fortuita, bem como é verdade que tanto Iugoslávia como Ruanda pagaram, posteriormente, os efeitos da sua submissão ao FMI a partir do fim dos anos 1970.

A propósito de Angola e de Moçambique, Löwy (idem, p. 78) diz-nos ainda que "[os] movimentos ditos tribais [...] são freqüentemente manipulados segundo os objetivos reacionários contra o nacionalismo". Agradeço o "freqüentemente" que se distingue, pois, de "sempre”. É verdade, eles são “freqüentemente” manipulados: mas não mais "freqüentemente" que os nacionalismos! Por que, então, dizer mais a propósito de uns que dos outros? E quais são esses nacionalismos (legítimos) contra os quais teriam lutado esses tribalismos (ilegítimos)? Os exemplos escolhidos por Löwy são particularmente infelizes. Os nacionalismos angolano e moçambicano são, precisamente, o arquétipo desses nacionalismos de Estado, elitistas, antipopulares, dos quais falamos anteriormente, que instauraram um Estado amplamente crioulo, dominado pelos únicos grupos étnicos da capital: sendo, nesse caso, autênticos... tribalismos. É totalmente falso apresentar a Renamo (grupo armado apoiado pelo apartheid na sua luta contra a Frelimo “marxista-leninista”) como um grupo tribalista: um grupo étnico dominou bastante a sua direção, mas seus segmentos são completamente pluriétnicos (aí compreendido o período atual [1996], a partir da sua transformação em partido civil: seu eleitorado é muito menos marcado etni- camente que o da Frelimo!). Certamente a Renamo conduz uma campanha contra a "dominação dos grupos do Sul”: mas onde está o tribalismo? $\mathrm{Na}$ denúncia de uma dominação étnica ou nessa dominação? Quanto à Unita (que conduziu a guerra contra o Movimento Popular de Libertação de Angola (MPLA) sustentado pelos cubanos), é impossível descrever aqui a sua longa trajetória: é verdade que a tendência, a partir de 1966, foi em direção a uma crescente etnicização em benefício de um único grupo, o Ovimbundu. Mas essa trajetória foi lenta, irregular e terminou somente no momento da retomada da guerra no início de 1993. E a etnização do lado do MPLA foi a mesma... Exprime-se aqui, de maneira explosiva, o problema da democracia política em um Estado sem nação, em que a regra da maioria significa, na prática, a dominação de um grupo sobre outro ${ }^{20}$.

O único bom exemplo de tribalismo escolhido por Löwy é o Inkhata de Buthelezi, que construiu, sobre a base de uma verdadeira etnicidade (zulu), um poder político ao redor do projeto instrumental de reconstituição de um Estado real zulu. Mas Buthelezi não teve nenhuma chance, pois o rei apoiou o ANC e os confrontos sangrentos que não cessam em Kwazulu não são, pouco importa o que propaguem os meios de comunicação, uma luta interétnica entre os "xhosas da ANC" e os "zulus da Inkatha”, mas uma guerra civil no seio da etnia zulu. E isso é simples de ser provado: todas as vítimas dessa guerra são zulus! O tribalismo de Buthelezi é verdadeiro e possui uma base social, mas não poderia, portanto, ser confundido com a etnicidade zulu inteira.

\section{UM NACIONALISMO “ANTI-IMPERIA- LISTA” E UM NACIONALISMO “INDÍGE- NA"?}

Löwy exalta amplamente as virtudes do "nacionalismo anti-imperialista”, nomeadamente na América Latina, sendo ele um especialista reconhecido sobre esse tema. Mais uma vez, não me estenderei sobre os pontos de acordo, em particular a respeito da análise sobre o EZLN (zapatistas do Chiapas), para poder concentrar-me nos problemas. Löwy escreve: “O nacionalismo, mesmo nas suas formas mais progressistas, não pode ultrapassar alguns limites” (idem, p. 81).

20 Sobre a questão angolana, ver: Messiant (1994a; 1994b; 1995a; 1995b); sobre a Renamo, ver Cahen (1995). 
Isto é uma asserção. "O nacionalismo, mesmo na suas formas mais progressistas”, é capaz de ultrapassar esses limites: isso não é a mesma coisa, isso não é inelutável; depende de toda uma série de fatores. O melhor exemplo é a Revolução Cubana: o patriotismo forneceu a base social de massa do Exército revolucionário que, inicialmente, não possuía um programa claramente definido. O processo de revolução permanente abrangeu nacionalistas anti-imperialistas que, como democratas conseqüentes, adotaram posições socialistas - sofrendo, em seguida, uma regressão devido ao isolamento econômico, social e político-cultural. Podemos dizer o mesmo do nacionalismo basco do ETA (VI ${ }^{\mathrm{a}}$ Assembléia), evoluindo na direção das idéias da IV Internacional (contudo, abandonando, na mesma ocasião, o nacionalismo). E o que se passa em Chiapas mostra bem que o nacionalismo pode ser perfeitamente uma forma de universalismo, como demonstra Löwy (idem, p. 80): "Encontramos nos documentos do Exército Zapatista de Libertação Nacional (EZLN) uma fusão, única em seu gênero, entre as tradições da revolução mexicana, a cultura maia dos indígenas do Chiapas e as idéias marxistas da esquerda latino-americana”.

Eis o futuro ${ }^{21}$ ! A etnicidade do Chiapas é uma etnicidade inter-nacionalista!

Mas a distinção operada por Löwy (ibidem) entre "nacionalismo anti-imperialista” e um "outro tipo de nacionalismo [...] o movimento dos indígenas por seus direitos” contém uma contradição. Certamente, as condições sociais, a experiência vivida, as condições ambientais etc., são bem diferentes no México e na floresta da Lacandona. As condições concretas de expressão do nacionalismo anti-imperialista "mexicano" são, pois, diferentes daquelas da insurreição indígena do Chiapas. Mas o fenômeno étnico seria em si diferente? A diferença está no fato de que se trata de etnias distintas 22 : de um lado, aquilo que alguns nacionalistas indígenas chamam de "espanhóis",

21 Entretanto, esse não é um caso completamente único em seu gênero. A história pode oferecer-nos outros casos (os marxistas irlandeses, o projeto de Partido Comunista Muçulmano de Sultan Galiev nos anos 1920 etc.). O problema é que foram muito pouco numerosos os marxistas a integrarem plenamente a problemática da libertação nacional ou étnica!

22 Etnias ou nações. Pessoalmente, não estabeleço nenhuma diferença conceitual entre "etnia” e "nação", sendo os a saber, os hispano-mexicanos e os mestiços e, de outro, as etnias e nações maias. Por isso, não considero útil a decomposição do fenômeno do nacionalismo em conceitos diferentes segundo as etnias que lhe concernem...

... A menos que Löwy traga à tona a idéia de que, entre os mexicanos, existiriam "aqueles que não possuem etnia”, unicamente a "nação mexicana”, e aqueles que teriam sido atingidos por essa praga: uma manifestação anti-imperialista urbana no México seria “nacional-mexicana”, isto é, “normal" e, com certeza, sem etnia, enquanto o antiimperialismo autóctone indígena seria "étnico"? Não vejo outra explicação que esse desvio latente da distinção realizada. De fato, ambos os lados possuem uma etnia: hispano-mexicanos e índios. Contudo, como os hispano-mexicanos possuem uma relação mais estreita com o Estado moderno que eles criaram e como são milhões reunidos na capital, identificamo-los mais facilmente com a nação inteira, sendo que as periferias indígenas permanecem “étnicas”. Isso é de um eurocentrismo - e mesmo de um jacobinismo clássico. Löwy aproxima-se muito do próximo passo, qual seja, o de hierarquizar semanticamente "nação" e "etnia" - a nação, maior, moderna, estatal, sendo "melhor" que a etnia, minúscula, peculiar, separatista, arcaica -, mas felizmente acaba por não o dar23.

dois casos expressões relevantes de uma comunidade imaginária projetada por um certo tipo de sentimento de pertença totalizante (um outro tipo próximo é constituído pelas comunidades religiosas). Nação e etnia são, no meu modo de ver, duas nuanças da etnicidade; eu empregaria a palavra "nação" para designar uma etnia particularmente cristalizada na intensidade e na duração histórica: "nação polonesa”, como também "nação congolesa” etc. Contudo, existem fenômenos “menos cristalizados”, mais voláteis ou bastante cristalizados, mas ainda recentes (islamobósnicos, por exemplo), os quais somente o recuo histórico dirá se eles produziram nações ou recuaram ao estado de simples relevância regional. Por isso, ao contrário dos jacobinos, distingo completamente os conceitos de nação e de Estado: a nação é uma comunidade imaginada, não é a população de uma República.

23 A hierarquização é, ademais, bem visível em nossa França jacobina: em nosso vocabulário, a "província” (e seu corolário pejorativo, "provincianismo”) jamais significa Paris. Os bascos, os corsos e os bretões, se são reconhecidos como nações, etnias ou simples regionalistas a serem visitados no verão, são, evidentemente, mais peculiares que "os franceses comuns"; os jornais publicados em Paris (Le Monde, Libération, Le Figaro etc.), incrivelmente 


\section{ETNICIDADE, NACIONALISMO E CONSCIÊNCIA DE CLASSE}

Para M. Löwy, o nacionalismo - e mesmo o anti-imperialismo - um dia deverá ser ultrapassado para ceder lugar ao universalismo socialista, ao socialismo. É esse o paradigma da etapa. Esse paradigma é, lembremo-nos, prevenido por Löwy que denuncia a atitude das correntes classistas que desprezam profundamente tudo aquilo que não seja diretamente relevante para a consciência de classe, tudo aquilo que não passa, segundo Engels e, sobretudo, Lukács, de "falsa consciência”"24. Mas as precauções não criam uma solução.

Em primeiro lugar, seria necessário saber se o nacionalismo pode ser universalista. Parece-me que a história, a começar pela Revolução Francesa, respondeu afirmativamente. E Chiapas confirma-o.

Mas é sobretudo a etapa em si que apresenta problema. Para os marxistas - e em particular os trotskistas - a construção da nação é sempre mais ou menos ligada à etapa da revolução democrático-burguesa. Certamente, segundo a visão bolchevique dos "países atrasados", nos quais a burguesia não resolveu essa tarefa, cabe ao proletariado realizá-la: ele deve, de certa maneira, trabalhar em dobro, marchar, mas... para poder passar adiante.

Essa visão não corresponde à realidade móvel dos fatos de consciência entre os indivíduos reais, cujo imaginário não funciona dessa maneira; ela, igualmente, produziu catástrofes na compreensão do processo de revolução permanente. A questão nacional não é, portanto, uma etapa em direção ao socialismo - que seria cada vez menos nacional, progressivamente planetário em direção à nação mundial. A questão nacional não é uma etapa: ela pode e talvez deva ser, imperativamente, um aspecto, um componente da revolução permanente, da revolução socialista e nela permanecer.

parisienses nas suas informaç̃os (ver a rubrica "Cinema" do Monde!) e na sua sensibilidade, são, no entanto, denominados "imprensa nacional”, enquanto Sud-Ouest ou Ouest-France, cujas tiragens são muito superiores aos títulos precedentes, são "regionais”... E, sobretudo, não falaremos que a "nação França” é uma etnia! Vejamos: isso é a Alemanha!

24 Cf. minha comunicação no Colóquio Marx Internacional: “Vrai débat pour 'fausse conscience'. Pour une approche marxiste de l'ethnicité” (CAHEN, 1997).
Assim, a revolução política na Ucrânia somente seria possível caso a questão nacional fosse resolvida, já que a opressão czarista - e depois stalinista - era ressentida como russa. A resolução dessa questão nacional teria possibilitado uma nova aliança entre os proletários de ambos os países, mas não por ser a Ucrânia menos ucraniana e a Rússia, menos russa! Talvez uma consciência nacional pan-soviética teria podido aparecer em um contexto democrático; mas nunca necessariamente em detrimento da relevância dos sentimentos nacionais, visto que uma nação pode ser, de fato, muito bem uma nação de nações. Um nível de identidade não exclui o outro.

O paradigma da etapa conduz à impossibilidade de compreender que, se a consciência de classe pode ser um fermento para a libertação nacional, a consciência nacional ou étnica também pode ser a expressão, uma forma, um contexto da consciência de classe.

Quando mexicanos, brasileiros ou franceses mobilizam-se contra o FMI ou contra a etapa maastrichtiana da mundialização capitalista, em que medida isso é nacionalista? É nacionalista considerando que os projetos capitalistas oprimem uma ampla comunidade de habitantes desses países, ou seja, algo mais vasto que as suas respectivas classes proletárias (isso é crucial no Terceiro Mundo, onde o proletariado é mais frágil). O movimento grevista de novembro-dezembro de 1995 na França foi notavelmente e ao mesmo tempo um grande movimento proletário e um movimento em defesa da idéia que possuímos da nossa República, a idéia que possuímos da França, um movimento de defesa etnonacional contra a agressão maastrichtiana. No Terceiro Mundo em particular, o nacionalismo anti-imperialista é a aliança de classes: nesse sentido - ressalto: nesse sentido - ele não é uma etapa em direção ao classismo; ele inclui-o e pode mesmo ser mais avançado que ele. Ele permite a transmissão de valores proletários a outros setores da população. Esse nacionalismo não é um passo "em direção a”, não é um passo "adiante” ou "prejudicial” em relação ao classismo: ele é uma forma possível e condensada da sua expressão.

Eis o motivo pelo qual - para citar um exemplo entre outros sobre a maneira segundo a qual os militantes marxistas do Terceiro Mundo concebem sua intervenção - aflige-me o fato de que a seção antilhana da IV Internacional mantenha a denominação “Grupo Revolução Socialista” em vez 
de, por exemplo, "Partido Independentista”.

Portanto, ao contrário do atual pensamento dominante de esquerda, pode-se afirmar que a época das revoluções nacionais está longe de terminar. Os nacionalismos continuarão a ser um importante fator de desenvolvimento histórico no século XXI, provocando, pois, uma verdadeira "nacionalização do mundo".

Nacionalismo de que tipo? Isso dependerá amplamente da capacidade ou da incapacidade dos marxistas de integrarem a questão étnico-nacional no programa da democracia política ${ }^{25}$.

25 Nota do autor (2008): fica em aberto o debate para sabermos se a expressão política de um movimento de li- bertação nacional deve ou não ser chamada de "nacionalismo". No meu modo de ver, essa seria a melhor solução conceitual, mas as “palavras” tornam-se, muitas vezes, uma armadilha no seu uso. Com efeito, faz-se necessária a distinção entre as doutrinas nacionalistas que erigem a nação como um essencialismo e uma realidade acima das classes, para a qual se deve estar pronto a morrer - essencialismos que se chamam também nacionalismos - e a dimensão política da expressão de uma sociedade que se ressente de uma identidade e que, como comunidade, sente-se oprimida e cujo "nacionalismo" é uma forma de internacionalismo. É, obviamente, nesse último sentido que utilizei o conceito de nacionalismo neste artigo. No caso francês, os vários movimentos de libertação encontram-se divididos sobre esse assunto: quando, por exemplo, os movimentos corsos mais radicais não hesitam em denominar-se "nacionalistas”, os seus congêneres bascos, que sempre se recusaram a isso, consideram-se "patriotas" (abertzale, na língua euskara) ou "internacionalistas" (pois dizem lutar para a igualdade de Direito de todas as nações).

Ângela Lazagna (angela_lazagna@yahoo.com.br) é doutoranda em Ciência Política na Universidade Estadual de Campinas (Unicamp).

Michael Löwy (lowym@free.fr; michael.lowy@orange.fr) é sociólogo e pesquisador do Centre National de la Recherche Scientifique (CNRS) (França).

Michel Cahen (m.cahen@sciencespobordeaux.fr) é historiador, pesquisador do Centre National de la Recherche Scientifique (CNRS) e Diretor-Adjunto do Centre d'Etude d'Afrique Noire (CEAN), do Institut d’Études Politiques (Université Montesquieu Bordeaux IV) (ambos na França).

\section{REFERÊNCIAS BIBLIOGRÁFICAS}

BOURGEOT, A. 1994. Les peuples heureux n'ont pas d'ethnie! In : VERNET, J. (dir.). Pays du Sahel. Du Tchad au Sénégal, du Mali au Niger. Paris : Autrement.

BRAGA, S. S. 2005. Resenha de "Intelectuais e política no Brasil. A experiência do ISEB”. Crítica Marxista, Rio de Janeiro, n. 23, p. 181184.

CAHEN, M. 1991. Le socialisme, c'est les Soviets plus l'ethnicité. In : . La nationalisation du monde. Europe, Afrique, L’identité dans la démocratie. Paris : Harmattan.

.1994. Ethnicité politique. Pour une lecture réaliste de l'identité. Paris : L'Harmattan.

1995. Dhlakama é maningue nice! Une guérilla atypique dans la campagne électorale au Mozambique. In : CEAN. L'Afrique politique 1995. Le meilleur, le pire et l'incertain. Paris : Karthala.
1996-1997. Nationalismes des Tiers mondes. Pour un débat, en réponse à Michaël Löwy. Critique Commnuniste, Paris, n. 147, p. 85-89, hiver.

1997. Vrai débat pour "fausse conscience". Pour une approche marxiste de l'ethnicité. Revue internationale de politique comparée, Bruxelles, v. IV, n. 1, p. 167-187, mai.

1999. Nationalismes des Tiers mondes. Pour un débat, en réponse à Michaël Löwy. In : _. La nationalisation du monde : Europe, Afrique. L'identité dans la démocratie. Paris : Harmattan.

2006. Lutte armée d'émancipation anticoloniale ou mouvement de libération nationale ? Processus historique et discours idéologique. Le cas des colonies portugaises, et du Mozambique en particulier. Revue Historique, Paris, v. CCCXV, n. 1, p. 113-138, jan. 
LÖWY, M. 1995-1996. Nationalismes du Sud. Critique Communiste, Paris, n. 144, p. 76-81, hiver. Disponível em : http://www.lcrlagauche.be/cm/index.php?option=com sectionnav\&view $=$ article $\&$ Itemid $=53 \&$ id =904. Acesso em : 7.set.2008.

1997. Patries ou planète? Nationalismes et internacionalismes, de Marx à nos jours. Lausanne : Page Deux.

2000. Nacionalismos e internacionalismos : da época de Marx até nossos dias. São Paulo : Xamã.

LÖWY, M. ; HAUPT, G. \& WEILL, C. 1974. Les marxistes et la question nationale 18481914 : études et textes. Paris : Maspero.

MARX, K. \& ENGELS, F. 2008 (1847-1848). Manifeste du Parti communiste. Disponível em : http://www.marxists.org/francais/marx/ works $/ 1847 / 00 / \mathrm{kmfe} 18470000 . \mathrm{htm}$. Acesso em : 15.set.2008.

MESSIANT, C. 1994a. Angola : Le retour à la guerre ou la faillite inavouable d'une intervention internationale. In : CEAN. L'Afrique politique 1994. Vue sur la démocratisation à marée basse. Paris : Karthala.

1994b. Les voies de l'ethinisation et de la décomposition. Lusotopie, Paris, p. 155-212, juil. (dir.). 1995a. Dossiê : L’Angola dans la guerre. Politique Africaine, Paris, n. 57, mars.

.1995b. Les voies de l'ethinisation et de la décomposition ( $2^{\mathrm{e}}$ partie). Lusotopie, Paris, p. 181-212, déc.

POULANTZAS, N. 1975. Pouvoir politique et classes sociales. 2 v. Petite collection Maspero. Paris : Maspero.

REIS, D. A. \& GOMES, A. C. 1996. Um intelectual marxista. Entrevista com Michael Löwy. Tempo, Niterói, v. 1, n. 2, p. 166-183. Disponível em : http://www.historia.uff.br/tempo/entrevistas/entres2-1.PDF. Acesso em : 15.set.2008.

TAMBIAH, S. J. 1997. Conflito etnonacionalista e violência coletiva no sul da Ásia. Revista Brasileira de Ciências Sociais, São Paulo, v. 12, n. 34, p. 5-24. Disponível em : http:// www.anpocs.org.br/portal/publicacoes/ rbcs_00_34/rbcs34_01.htm. Acesso em : 15.set.2008.

TORGA, M. 1994. L'universel, c'est le local moins les murs. Trás-os-Montes. $2^{\mathrm{e}}$ ed. Bordeaux : W. Blake.

TOSCANE, L. 1995. L'Islam, un autre nationalisme? Paris : Harmattan.

\section{OUTRAS FONTES}

Actuel Marx. 1995. L’Impérialisme aujourd'hui. Paris, n. 18, Deuxième semestre.

FORO DE SÃO PAULO. 1990. Declaración de São Paulo. Disponível em : http:// www.pt.org.br/portalpt/foro/arquivos/ Declaraciones\%20finales.zip. Acesso em : 15.set.2008.
Inprecor. 1990. Paris, n. 6, p. 6, juil.

Mexique : nouvelle relation entre les peuples indiens et la societé. 1995. Inprecor, Paris, n. 387, p. 4-7, jan. 
NATIONALISMS AND INTERNATIONALISM: THE MICHEL LÖWY-MICHEL CAHEN DEBATE

Ângela Lazagna, Michel Löwy and Michel Cahen

This article is made up by a debate that went on between Michel Löwy and Michael Cahen in the mid-1990s that has been edited for this publication. Although the discussion refers to events that to a certain extent may be considered dated here, the underlying concern these articles share provides their current relevance: the need for deepening reflections, via Marxist theory, on the problem of national and internationalism in times of globalization. This deepening, according to the authors, demands reflections that offer a critical break with the Eurocentrist view of different nationalisms and go beyond the attitude of many Marxists who held everything that was not directly related to "class consciousness" in disregard.

KEYWORDS: nationalisms; internationalism; Marxism; Eurocentrism; globalization; class consciousness. 
NATIONALISMES ET INTERNATIONALISME: UM DÉBAT ENTRE MICHAEL LÖWY ET MICHEL CAHEN

Ângela Lazagna, Michel Löwy et Michel Cahen

Cet article porte sur un débat réalisé entre Michel Löwy et Michael Cahen au milieu des années 1990 et est révisé pour cette publication. Même si la discussion se reporte à des événements qui d'une certaine manière peuvent être considérés comme datés, la préoccupation de fond, assez courante en ce qui concerne ces articles, la rend actuelle : il faut approfondir la réflexion, à partir de la théorie marxiste, sur le problème des nationalismes et de l'internationalisme sous l'ère de la 
mondialisation. Cet approfondissement, selon les auteurs, est nécessaire surtout par l’intermédiaire d'une réflexion qui provoque d'une façon critique la rupture de la vision eurocentrique des différents nationalismes et qui dépasse l'attitude de plusieurs marxistes qui ignorent tout ce qui ne soit pas directement lié à la "conscience de classe”.

MOTS-CLÉS : nationalismes ; internationalisme ; marxisme ; eurocentrisme ; mondialisation ; conscience de classe. 